\title{
Gender and age aspects of child psychological defenses in child-mother relationships
}

\author{
Maria V. Bogdanova ${ }^{a^{*}}$, Irina A. Rusyaeva ${ }^{\mathrm{a}}$, Anastasia O. Vyelgzhanina ${ }^{\mathrm{b}}$ \\ a Institute of Psychology and Pedagogy, Tyumen State University, Tyumen, Russia \\ ${ }^{\mathrm{b}}$ Institute of Finance and Economy, Tyumen State University, Tyumen, Russia \\ *Corresponding author. E-mail: bogdanova-mv@yandex.ru
}

\begin{abstract}
The high level of stress in modern society poses a need to study family factors and resources for the development of children's defense mechanisms in the current social environment. This study investigates correlations between maternal and child psychological defense mechanisms, using interviews, a structured clinical survey, projective drawing, and a projective game. Analysis of data from 240 people (120 children and 120 mothers) revealed specifics of the formation of psychological defense mechanisms among children aged 4 to 12 years in child-mother relationships. We suggest that maternal and child defense mechanisms have some isomorphic traits, but the level and quality of isomorphism changes with each age period of the child. Certain defensive mechanisms of mother and child appear with the same frequency. The child's gender influences the correlation between the mother's and child's psychological defense mechanisms. Initially, children are more likely to directly copy defense mechanisms observed from the mother's behavior. As they grow older, they use defenses that they have learned consciously. Based on empirical data, we also found a correlation between the maturity of the maternal psychological defense mechanisms and specifics of child psychological defense mechanisms. We propose that the maturity of maternal psychological defense mechanisms has the greatest meaning for child psychological defense mechanisms at the earliest stages of ontogenesis - it provides consistency between the mother's own psychological defense mechanisms and the psychological defense mechanisms that she teaches her child.
\end{abstract}

Keywords: psychological defense mechanisms, coping strategies, child-mother relationships, maternal teaching

\section{Introduction}

A constructive psychological defense mechanism (PDM), which implies rare resort to such negative defenses as denial, regression, or reaction formation, is associated with a high level of personal hardiness (Filippovich, 2014). Many Russian and international scientists have studied how the family influences a developing 
child's psychological defenses and coping behavior (M. Maler, M. Klein, A. Freud, J. Bowlby, D. Winnicott, I. Nikolskaia, R. Granovskaia, A. Zakharov, T. Kriukova, E. Kuftiak, E. Eidemiller, V. Yustickis, and others). A child's defensive repertoire is formed in child-parent relationships, when the child faces situations that can be identified as traumatic, ambiguous, and threatening to child's identity (Docenko, 2009; Eidemiller \& Yustickis, 1999; Leontiev, 2009; Nikolskaia \& Granovskaia, 2001). Both the general family situation and the parents' defensive behavior influence a child's defensive repertoire (Ainsworth, 1977; Bowlby, 1982; Eidemiller \& Yustickis, 1999).

The system of psychological defenses in the context of this research is defined as an implicit scheme of reacting to basic difficulties in life, which prevents the personality from losing its identity. The effectiveness of this system is closely connected with personal hardiness and coping abilities; it provides moderate filtration and processing of traumatic information, and a constructive system defends the personal identity without losing touch with reality.

A. Freud (1936) first discovered the important role of the microsocial environment in the development of the child's psychological defenses, while she was studying their meaning for resolving external sociogenic conflicts. She examined such defense mechanisms as perceptive, intellectual, and motor automatisms of different complexity levels, which are formed in the process of volitional and involuntary learning. Traumatic events in early interpersonal relationships were hypothesized to be a key factor in the development of psychological defense mechanisms.

Russian psychologists have also studied parent-child relationships a great deal (G. Burmenskaia, M. Buianov, A. Varg, B. Garbuzov, V. Lebedinskii, E. Sokolova, V. Stolin, E. Eidemiller, V. Yustickis, and others). Thetructure and dynamics of coping strategies in a family and the role of physical punishment in a family were studied by E. Kuftjak $(2012,2013)$. The experiments of E. Sokolova $(2011,1989)$ revealed that parental emotional rejection and emotional symbiosis block the child's tendency for rejection or attraction, respectively. These disturbances can develop in the child a feeling of helplessness and can trigger the formation of psychological defense mechanisms. The ontogenesis of psychological defenses is a heterochronous process of formation of new adaptive forms of behavior, which have both a conscious and unconscious character (Portnova \& Bogomolov, 2008).

Gender differences have been well studied at the preschool age. Nevertheless, researchers have focused mainly on general differences in children's behavior. Thus, it is well known that boys are more active, and they aggressively explore the environment; they are disposed to independence and isolation, whereas girls are more disposed to social contact and friendship (Kostikova, 2000). In addition, girls' speech development proceeds more rapidly in preschool and primary school than boys' speech (Ushakova, 2006). P. Cramer and W. College (2000) argue that defenses directed toward other people (transferring one's own conflict to environment) are more typical of men, whereas defenses implying changes in personal perception of events are more typical of women (Solovyova, 2013). Considering these gender specifics, we suggest that boys' prevailing defense mechanism is avoidance and they are disposed to isolation, whereas girls tend to seek social support more actively and use mostly verbal defense mechanisms. 
With respect to age and the specifics of children's psychological defense mechanisms, Belova (2011) showed that the disreplacement defense mechanism is more frequently used at primary school age than at preschool age, which could be due to the child's engaging in an aggressive environment.

Nikolskaia and Granovskaia (2001) investigated gender differences in children's psychological defense mechanisms in primary school. They argued that "old" defense mechanisms, formed at preschool age, are consolidated at the age of 7-12. Boys tend to active intervention in a situation (struggling, fighting, verbal abuse) twice as often as girls, emotional discharge, and are disposed to withdrawal and distraction (dreaming, relaxation), whereas girls tend to seek social support (crying, hugging). Hence, boys discharge their emotions by social aggression and girls seek sympathy and understanding as a base of support in coping with difficult situations. The phenomena of children adopting the defensive and coping behavior of adults has also been well studied by many researchers (Kuftiak, 2012, 2013). Nevertheless, the specifics of psychological defenses in a mother's interactions with her son or daughter have still been insufficiently explored.

Based on existing knowledge about children's psychological defense mechanisms, we can say that their development is shaped by both environmental factors (social situation, microsocial relationships) and inherent factors (gender, specifics of intellectual and emotional development, age). As the psychology of personality is a complex system concept, psychological processes should be investigated using a systems approach. Studies of the I-conception, personality development, self-realization, and system determination have been conducted according to the system approach (Asmolov, 2007). Existing scientific models and concepts focus on different aspects of the function of psychological defense mechanisms, but do not give a clear picture of the developing child's psychological defense mechanisms in the context of child-mother relations.

\section{Method}

In psychological science and clinical practice, the mother more often than the father plays the most active role in the child's upbringing and responds to the child's request for psychological support. The goal of this research is to discover specifics of interconnection between child and maternal psychological defense systems, in relation to the child's gender and age. We assume child-mother relationships to be the basis of forming the child's defenses.

We conducted the following research tasks:

1. We analyzed the correlation between maternal maturity and the child's psychological defense mechanisms.

2. We tested our hypothesis about the isomorphism of the mother's and child's psychological defense mechanisms in different age groups.

3. We searched for common characteristics among children's psychological defense mechanisms (intensity of stress perception, sociability, level of selfesteem, need for additional defenses, and anxiety level). 
This study is generally based on the system approach, particularly the holistic concept of developing psychological defenses in one's personal life support system. This involves a multilevel system of psychological reactions, the main functions of which are protecting personal integrity, providing optimum adaptation to life circumstances, and discovering the necessary resources for personal development (Belova, 2011). Scientific knowledge about psychological defenses can be systematized based on the concept of a personal life-support system, taking into consideration all significant factors of their formation (age and gender, threats to the child's identity, resources, and maturity of the maternal psychological defense mechanisms). This methodological approach allows us to investigate interactions of maternal and child defensive systems in diverse aspects and to draw prognostic conclusions.

In our research, maternal "teaching of psychological defense mechanisms" refers to the purposeful transfer of skills and knowledge, that is the mother's verbal instructions, advice, explanations to the child about how to react to stress, or nonverbal encouragement and direction of the child's defensive behavior in the way she considers best for the child.

The maturity of a psychological defense mechanisms is an integral concept, implying a wide range and great flexibility of defensive repertoire. It can be measured

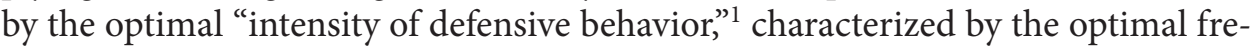
quency of using defense mechanisms and the prevailing usage of secondary (higher level) psychological defense mechanisms (Docenko, 2009; Nikolskaia, 2012). Mature maternal psychological defense mechanisms use mostly constructive defense mechanisms and the maternal teaching process corresponds to the mother's own defensive behavior. This has great meaning for the consistency of upbringing. A mother with mature psychological defense mechanisms is more conscious of what she is doing, and her verbal teaching is supported by experience; she uses in her own behavioral practice the psychological defense mechanisms that she teaches. Congruency and consistency between the mother's defensive behavior and her verbal teaching provide favorable conditions for the child's interiorization of the psychological defense mechanisms that his or her mother has approved.

To group the mothers in our sample according to the maturity of their psychological defense mechanism system, we used both quantitative and qualitative approaches. First, we defined three groups on the basis of data on the difference between the quantity of constructive and destructive defenses. We verified the results with the "Life Style Index" questionnaire, using expert assessment. Five experts in family psychological clinical practice and competent in issues of PDM were asked to divide the mothers into three groups of PDM maturity, based on the mothers' answers to a structured interview. Then we compared the results of the grouping by relatively qualitative and quantitative methods. The results matched completely.

1 The intensity of defensive behavior was defined as the intensity of defense mechanisms in behavior. It was calculated on the basis of the "Life Style Index" questionnaire, developed by Plutchik, Kellerman, and Konte (1979), using the following formula: $n / 92 \times 100 \%$, where $n$ is the sum of all checked answers in the questionnaire. 
Methods for this study were chosen in accord with the main research purpose. They are questioning, interviewing, testing, and projective methods (drawing, game).

For gathering data about mothers, we used:

1. A structured interview, which was necessary for the psychological anamnesis and to gather information about qualitative specifics of the mother's psychological defense mechanisms and the child's defensive behavior in threat situations.

2. The "Life Style Index" questionnaire, developed by Plutchik, Kellerman, and Konte (1979) and adapted for Russian samples by Romanova and Grebennikov (1996) and by Vasserman, Eryshev, and Klubova (2005). The method identifies eight basic defensive mechanisms (denial, repression, displacement, compensation, reaction formation, projection, intellectualization, and regression) and helps to identify prevailing primary or secondary personal defenses. This instrument is introduced in a convenient standardized form and has high diagnostic capability for this research.

For gathering data about children, we used:

1. The method of serial drawings and stories developed by Nikolskaia (2010). It has sufficient diagnostic value in work with children because of its consistent conversations based on drawings. The conversations proceed as a sequence: making contact, identifying a stressful situation, and coping with stress, including bringing to bear the child's inner resources. Stories suggested for drawings have such topics as "I am", "When I'm sad", "It is hard for me", "Something I do not want to remember", "I'm so glad, I'm so happy" (Nikolskaia, 2010).

2. A projective game called "Finish the Story", which allows projection of the child's emotional statements, coping techniques, and psychological defenses in a maximally natural way, because of the comfortable and safe situation of a game. Our choice of this method was based on the assumption that games are the main and most natural activity of a child (Elkonin, 1999; Vygotsky, 1982).

3. A projective drawing method called "Person under the Rain", which provides information about the strength of the child's Ego development, stressresistance, and coping with stressful situations. This method is used to diagnose personal reserves and to identify the specifics of defense mechanisms.

We used data about types and frequency of defenses expressed by children in correlation analysis to investigate relationships between the mother's and child's psychological defense mechanisms. The "Person under the Rain" method of projective drawing was used for verification of data about the child's PDM gathered by mean of the first two methods.

Sample characteristics. In total 240 people were tested, including 120 mothers and 120 children (64 girls and 56 boys). There were 57 children aged 4 to 6 years, 31 children aged 7 to 9 years, and 32 children aged 10 to 12 years. 
Data analysis was carried out in the following sequence:

1. Examination of correlations between maturity level of maternal psychological defense mechanisms and specifics of the children's psychological defense mechanisms:

a) Classification of mothers in groups by maturity level of psychological defense mechanisms on the basis of the "Life Style Index" questionnaire and verified by experts;

b) Verification of the classification of the groups by discriminant analysis;

c) Examination of correlations between maturity level of maternal psychological defense mechanisms and specifics of interpersonal behavioral defenses using the Spearman coefficient test p-values.

2. Investigation of isomorphism of maternal and child psychological defense mechanisms;

3. Investigation of common characteristics among children's psychological defense mechanisms (intensity of stress perception, sociability, level of selfesteem, need for additional defenses and anxiety level).

Methods of data analysis: content analysis, Kruskal-Wallis test, Spearman coefficient test $\mathrm{p}$-values, discriminant analysis, frequency analysis. For processing data, we used the professional software SPSS Statistics 19.0.

\section{Results}

Expert analysis yielded three groups of mothers, verified by discriminant analysis:

1. 23 mothers with low maturity of psychological defense mechanisms;

2. 66 mothers with average maturity of psychological defense mechanisms;

3. 31 mothers with high maturity of psychological defense mechanisms.

In the group of children aged 4 to 6 , we found differences in the intensity of defensive behavior and discovered that this intensity correlates with the maturity of the maternal psychological defense mechanisms $(\mathrm{p}=0.023)$. Using psychological defenses as the reaction to an insignificant stimulus indicates the enhanced intensity of the defense system. The higher the maturity of maternal psychological defense mechanisms, the more psychological defenses appear in the child's behavior. Intensive use of psychological defenses in childhood has a constructive meaning, because it decreases the probability of psychosomatization until higher reactions are actualized (see Figure 1).

We visualized the intensity of children's psychological defense mechanisms based on quantitative data, gathered by means of projective games and drawing methods. These data were rated from 0 up to 25 cases of using psychological defense mechanisms in behavior. We found notable differences between the mean values of intensity of children's psychological defense mechanisms in different groups, classified by level of maturity of maternal psychological defense mechanisms. In the group of mothers with infantile psychological defense mechanisms, the mean value 
of intensity is 8 ; for mothers with average maturity of psychological defense mechanisms, this indicator is 9; and in the group of mothers with mature psychological defense mechanisms, it is 11.5.

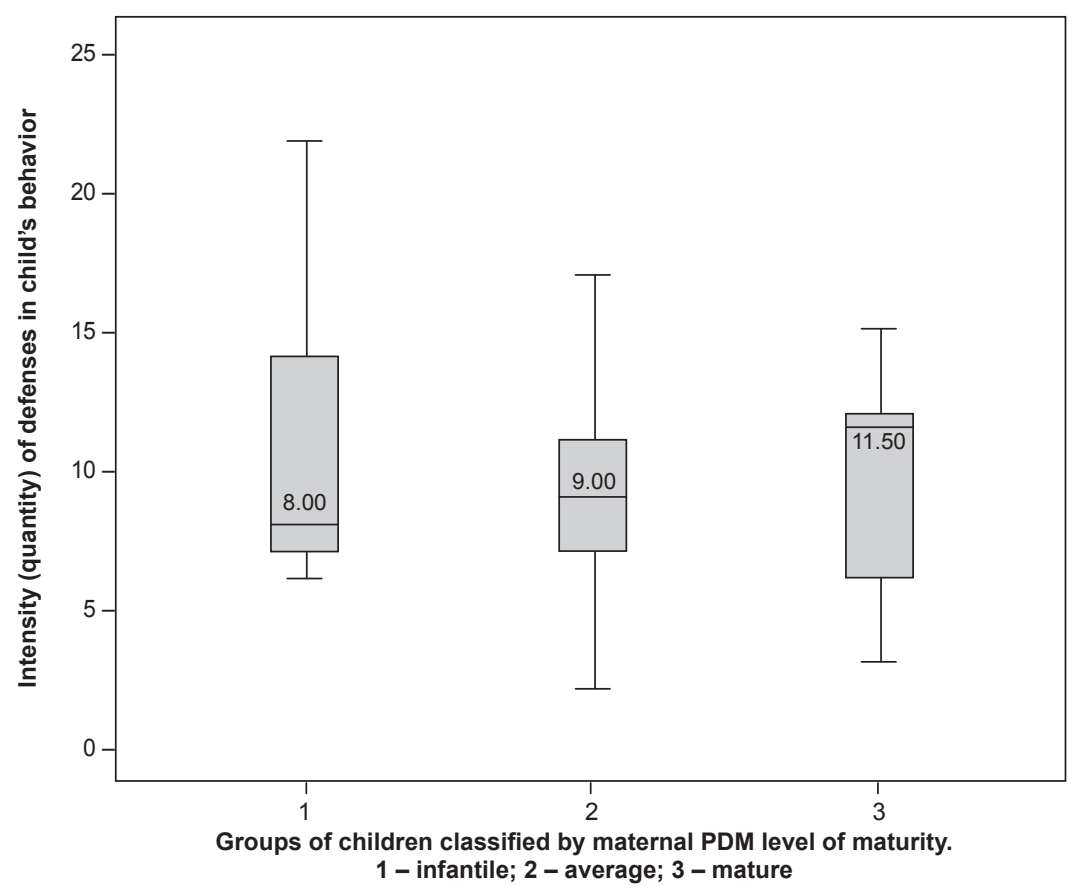

Figure. 1. Differences in intensity of the psychological defense mechanisms among children 4-6 years old, classified in groups by the maturity of their mothers' psychological defense mechanisms.

In the group of children aged 7 to 9 years, we found differences in the frequency of using projection defense mechanism in behavior and a connection of this indicator with the maturity of maternal psychological defense mechanisms. Higher maturity of maternal psychological defense mechanisms correlates with higher frequency of the child's using projection. Children use the projection defense mechanism (see Figure 2) for better adaptation to school and to criteria for grading of students' work. They project part of their feeling of failure onto external objects and therefore enhance the stability of their identity and self-esteem. In the group of mothers with an infantile defense system, the frequency of use of "projection" in the child's behavior did not exceed once (mode 1); in the group of mothers with average maturity of psychological defense mechanisms, the frequency of use of "projection" in the child's behavior varied from once to twice, with the most frequent use being once (mode 1); in the group of mothers with mature PDMs, the frequency of use of "projection" by the children varied from 1 to 3 times, with the most frequent use being twice (mode 2).

In the group of children aged 10 to 12 years, we did not find statistically significant specifics conditioned by the maturity of maternal psychological defense mechanisms. 


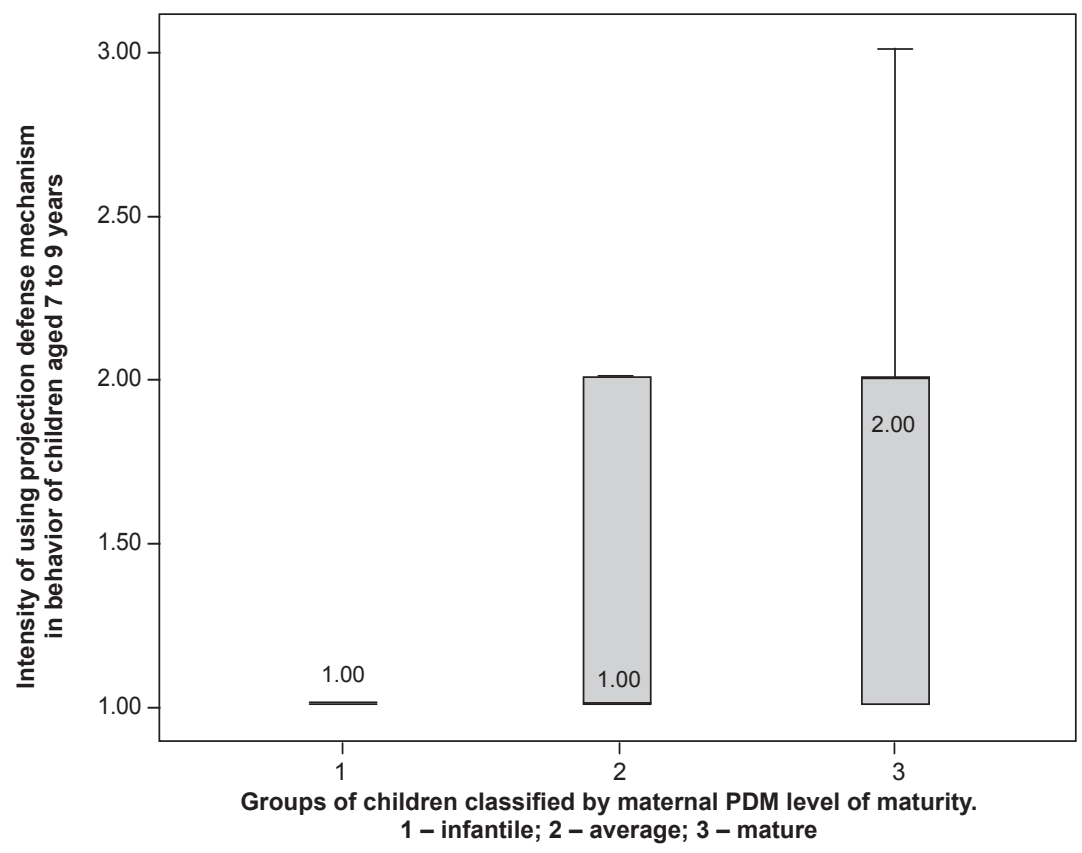

Figure 2. Differences in intensity of psychological defense mechanisms among children aged 7-9 years, classified in groups by the maturity of their mothers' psychological defense mechanisms.

We used the Spearman coefficient test p-values for studying the isomorphism of maternal and child psychological defense mechanisms. In the group of children aged 4 to 6 years, correlations between child and maternal psychological defense mechanisms are ambiguous. Mothers' behavior correlates with the frequency of using certain defense mechanisms by the child, such as "repression" ( $p=0.021)$, "displacement" ( $p=0.001)$, and abilities to negotiate in conflict situations $(p=0.026)$. If the mother teaches the child intellectualization as a reaction to difficulties, the child is more likely to use intellectualization as a desired defense mechanism in the projective game $(\mathrm{p}=0.048)$. Gender specifics of isomorphism between maternal and child defense systems are described in Table 1.

We propose that a child's gender is a significant factor in the relation of maternal and child psychological defense mechanisms. In our sample, boys are disposed to copy the defense mechanism "repression" from their mother's behavior $(p=0.04)$, and girls tend to copy the defense mechanism "displacement" $(\mathrm{p}=0.015)$.

Boys predominantly acquire skills of negotiating $(\mathrm{p}=0.006)$ and emotional reaction $(\mathrm{p}=0.036)$ in the process of maternal teaching, and girls use intellectualization in their behavior more successfully $(\mathrm{p}=0.031)$.

Girls are disposed to perceive the defense mechanism "denial" as an approved one, as it appears in the projective game, because of learning $(\mathrm{p}=0.033)$. Intensity of maternal teaching (the intensity of defenses in maternal teaching) correlates with the intensity of girls' psychological defense mechanisms. Intense efforts of the mother to teach her daughter psychological defenses increase the probability of high intensity of the girl's psychological defense mechanisms $(\mathrm{p}=0.042)$. 
Table 1. Correlations between intensity of maternal and child psychological defense mechanisms in the group of children aged 4 to 6 years, by gender

\begin{tabular}{|c|c|c|}
\hline \multirow{2}{*}{ Maternal and child psychological defenses } & \multicolumn{2}{|c|}{ Correlation coefficient, $\mathbf{p}$-value } \\
\hline & Girls & Boys \\
\hline Repression in maternal and child behavior & - & $\begin{array}{c}0.423 \\
0.04\end{array}$ \\
\hline Displacement in maternal and child behavior & $\begin{array}{l}0.418 \\
0.015\end{array}$ & - \\
\hline Denial in maternal teaching and child learning & $\begin{array}{l}0.373 \\
0.033\end{array}$ & - \\
\hline $\begin{array}{l}\text { Intellectualization in maternal teaching and child } \\
\text { behavior }\end{array}$ & $\begin{array}{l}0.376 \\
0.031\end{array}$ & - \\
\hline Intensity in maternal teaching and child behavior & $\begin{array}{l}0.356 \\
0.042\end{array}$ & - \\
\hline $\begin{array}{l}\text { Reaction formation in maternal teaching and in } \\
\text { child behavior }\end{array}$ & - & $\begin{array}{l}0.431 \\
0.036\end{array}$ \\
\hline $\begin{array}{l}\text { Negotiating skills in maternal teaching and in } \\
\text { child behavior }\end{array}$ & - & $\begin{array}{l}0.547 \\
0.006\end{array}$ \\
\hline
\end{tabular}

In the group of children aged 7 to 9 , we found a correlation between maternal support in training a child's psychological defenses and maternal support in the projective game. The more often the mother uses the defense mechanism of "seeking and getting support" and encourages her child to apply it, the better it is expressed in the child's behavior as a psychological defense mechanism that is desired and acquired in the learning process $(\mathrm{p}=0.041)$.

We noted gender specifics of children's psychological defenses in the age group of 7-9 years. The boys were disposed to learn their mother's defense mechanism "repression" ( $p=0.04)$, and the girls to learn their mother's defense mechanism "displacement" $(\mathrm{p}=0.015)$. Boys predominantly acquire skills of negotiation $(\mathrm{p}=0.006)$ and emotional reaction $(\mathrm{p}=0.036)$ in a process of maternal teaching, and girls used intellectualization more successfully $(\mathrm{p}=0.031)$. Girls were disposed to perceive the psychological mechanism "denial" as approved. Hence, the psychological defense mechanism "denial" can be identified in the projective game as a result of learning $(p=0.033)$. The intensity of maternal learning (intensity of defenses) correlates with the intensity of girls' psychological defense mechanisms. Intense efforts by the mother to teach girls psychological defenses increases the probability of high intensity of girls' psychological defenses $(\mathrm{p}=0.042)$.

There is a stronger correlation in this age group between mothers' and boys' psychological defense mechanisms (Table 2). Boys have the same tendency to learn the psychological defense mechanism "repression" from their mother's behavior as in the previous period, age 4-6. Correlation between expression of the child's desired psychological defense mechanism "seeking and getting support" and the mother's effort to train and encourage her child to use this defense mechanism is approximately the same at age $7-9(\mathrm{p}=0.02)$.

The more the mother teaches a boy the defense mechanism "reconciliation", the more often we find it in his behavior $(\mathrm{p}=0.005)$. Boys aged 7-9 are sensitive 
both to maternal psychological defenses, which were significant for them at the previous age period, and to new psychological defenses. These new psychological defense mechanisms are connected with rejection of independence and ambitions; examples are "conciliation" and "seeking support". This situation is very important for boys' upbringing from the standpoint of forming gender identity.

Table 2. Correlations between intensity of maternal and child psychological defense mechanisms in the group of children aged 7 to 9 years, by gender

\begin{tabular}{lcc}
\hline \multicolumn{1}{c}{ Psychological defenses of mother and child } & $\begin{array}{c}\text { Correlation coefficient, p-value. } \\
\text { Boys }\end{array}$ \\
\hline Psychological defenses of mother and child & Girls & - \\
& -0.557 & 0.551 \\
"Displacement" in mother's behavior & 0.025 & 0.033 \\
"Seeking for and getting support" in maternal teaching & - & 0.593 \\
and child learning & - & 0.020 \\
"Reconciliation" and "consciousness" in maternal & - & 0.681 \\
teaching and child behavior & & 0.005 \\
\hline
\end{tabular}

We found negative correlation between girls' and their mothers' emotional reactions. The more impulsive the mothers' emotional reaction, the less girls demonstrate it in their behavior $(\mathrm{p}=0.025)$. We propose that avoidance of emotional reactions in the child's behavior is connected with low child tolerance of maternal emotions.

In the group of children aged 10 to 12 , we found new positive correlations between maternal teaching and child behavior. The children were disposed to acquire the defensive skills "displacement", "compensation", and "tendency to reconciliation" from maternal teaching. We found a positive correlation between intellectualization in maternal and child behavior $(\mathrm{p}=0.034)$ and intensity of maternal and child psychological defense mechanisms $(\mathrm{p}=0.009)$.

Table 3. Correlations between intensity of maternal and child psychological defense mechanisms in the group of children aged 10 to 12 , by gender

\begin{tabular}{lcc}
\hline Psychological defenses of mother and child & $\begin{array}{c}\text { Correlation coefficient, p-value } \\
\text { Girls }\end{array}$ & Boys \\
\hline Displacement in maternal teaching and child behavior & 0.732 & - \\
Defensive aggression in maternal teaching and child & 0.002 & - \\
behavior & 0.650 & - \\
\hline
\end{tabular}

Gender specifics show an absence of any significant correlation between maternal and child results in the group of boys aged 10 to 12 .

In the group of girls aged 10 to 12 , we found a positive correlation between "displacement" in maternal teaching and child behavior. The more the mothers taught girls "displacement", the more often their daughters used it $(\mathrm{p}=0.005)$. In addition, 
we can propose that girls are capable of adopting and using defensive aggression from maternal learning $(\mathrm{p}=0.009)$. This is similar across all age groups of girls in the research sample.

As for general characteristics of the child's defensive system, we found statistically significant age differences in the need for additional support $(p=0.012)$ and for intensity of stress perception $(\mathrm{p}=0.001)$

The need for additional support tends to increase with maturation. It appears as a lack of self-confidence, decreasing self-sufficiency and psychological stability in stress situations. This situation can strengthen those psychological defense mechanisms that are inadequate to providing quality protection of the personality from threat; this requires a new personal life-support system, in particular conscious coping.

The intensity of stress perception is more evident at primary school age (see Figure 2). Increasing sensitivity of primary schoolchildren to stress appears in view of their increasing vulnerability to actual threats and their perception of stress situations as fearful and unpleasant. Perhaps this is caused by entering school, which means immersion in a new social environment with new rules and the need for adaptation to changes that encompass all areas of life.

\section{Discussion}

\section{Ontogenetic specifics of psychological defenses of children 4-6 years old}

1. The preschool age is one of the most significant for developing psychological defenses. Preschoolers have rapidly developing cognitive processes, which act as defenses. The environment gives more and more opportunities for a child to gain knowledge and self-expression. Communication in the family and in a group of peers is a context in which a child realizes age-related development tasks: taking initiative, autonomy, and adaptation of social roles.

That is why the main threat are to feelings of success, independence, and selfesteem. Psychological defenses that are forming in an interpersonal relationship with a significant adult, primarily the mother, help the child to cope with frustration. The maturity of maternal psychological defense mechanisms at this stage of development defines the child's resources for developing psychological defense mechanisms to a great extent. The mother who has relatively mature psychological defense mechanisms tends to have a maximum aspiration for excelling as a parent, because she is able to create conditions for constructive development of her child's psychological defense mechanisms. She is notable for her consistency in upbringing: Her own behavioral defenses are coherent with what she teaches her child; she is able to use higher psychological defenses and is ready to support her child in difficult situations. The defensive behavior of a mother with mature psychological defense mechanisms is flexible and variable; it is typical for her to analyze a situation, learn the lessons of a traumatic experience, and reflect upon her feelings.

In our research, we discovered a positive correlation between the maturity of maternal psychological defense mechanisms and the intensity of the child's psychological defense mechanisms. Increased intensity of the defense system is an optimal 
way to adapt in childhood, which helps preserve the child's positive self-image and emotional comfort, and decreases the probability of a psychosomatic reaction to stress.

The child's psychological defense mechanisms at the age of 4-6 has traits similar to the mother's psychological defense mechanisms, first of all with her interpersonal behavioral defenses. The child successfully copies her repression, displacement, and negotiating defenses and demonstrates them in his or her behavior.

2. It is interesting that children can already learn higher-level defenses at preschool age. These may not appear in a child's behavior, but occasionally he or she practices them in games. According to Winnicott (2002), it is important acting with understanding the sense from the very early ontogenesis period. In our research, we found a positive correlation between maternal teaching of the intellectualization defense mechanism and its acceptance by the child as desirable; the child then uses it in games.

3. At 4-6 years, the child's gender has a significant influence on the defenses that the child perceives in the child-mother relationship and reproduces behaviorally. Girls have more tense connection with maternal psychological defense mechanisms than do boys. Girls tend to copy displacement from maternal behavior, whereas boys copy repression. This can be explained partially by gender specifics of upbringing: often expression of aggression is not accepted for girls, and crying or showing weakness is not accepted for boys. When the child finds an appropriate model in maternal behavior, he or she can apply it.

As for the success of maternal teaching of psychological defenses, it is easier to teach girls to deny difficulties, which they readily demonstrate in games. In the mass media, the image of the "weak", "passive" woman (girl), who denies her ability to solve a difficult situation and looks for pleasure (chocolate, a new dress, etc.) is very common. In a game, girls often tend to neutralize problems, denying them, especially if their mothers teach them to do it.

Opportunities for conscious training in defense strategies depend on gender. Girls learn intellectualization faster and demonstrate it in their behavior. In general, the intensity of maternal teaching correlates with the intensity of girls' defense systems, not only by the mother's example but also verbally.

Boys, on the other hand, are more successful in learning emotional reactions and negotiation defenses. Teaching them how to react is a demonstration of the mother's care and consideration of her son's inner world, and he is sensitive to the training of this psychological mechanism. Reproducing negotiation skills among boys is necessary for social relationships and constructive dialogue. This is an indication of future competence.

Therefore, maternal defense resources are an important basis of forming child psychological defense mechanisms at the age of 4-6, and provides resistance to difficulties, as appropriate for this age.

\section{Ontogenetic specifics of psychological defenses of children 7-9 years old}

The social situation of primary schoolchildren is quite different from that of the preschool age. The main task children face is that of switching their main acti- 
vity from playing to learning. Increasing their voluntary behavior, developing selfcontrol and self-reliance, are significant tasks of this age period.

The maturity of the maternal PDM system correlates with the frequency of projection in the child's behavior at the age of 7-9. The more mature the psychological defense mechanisms of the mother, the more frequent her child's use of projection in behavior. Although projection is one of the most primitive defense mechanisms, at this age it plays an adaptive role. At the time of entering school, the child's I-concept is especially vulnerable, because the teacher's grading of the child's work is a threat to self-esteem, and in relationships with peers, competition and the judgments of others become more important. At the age of 7-9, we find a correlation between the child's heightened intensity of stress perception and increased emotionality. At this time the child becomes especially sensitive to stress and needs the protection of a stable self-image and environment, and the need for safety must be satisfied. Projection helps the child to adapt to difficulties connected with self-esteem, preserving a positive self-image in situations of underachievement, external assessment, or loss of a leading position.

At the age of 7-9, in the process of maternal teaching, children successfully adopt a strategy of seeking and getting support and reproducing this in a game situation. Skills of getting help constructively promote a child's social effectiveness and collaborative activity. The child practices this important skill in the playing process, for its future use in difficult situations.

Gender can influence many relationships between mother and child at age 7-9, as well as specifics of the child's defense system.

We propose that maternal defensive behavior continues to set an example for boys, but they mostly copy a displacement strategy. Boys also successfully adopt from maternal teaching a strategy of seeking and getting support and an aspiration for reconciliation.

According to common cultural notions about gender, aspirations for reconciliation and seeking support are more proper for girls than for boys. Such a strategy in boys' behavior can be caused by a deficit of teaching of traditional male behavioral strategies in conflict, which are more aggressive and stubborn. At this stage, the father's participation in the child's learning and the example set by the father's behavior are important for the development of strategies that satisfy the boy's need for achievement, as well as strategies of reconciliation and intellectualization.

We conclude that girls 7-9 years old have psychological defense mechanisms that depend less on those of their mother. The maternal reaction strategy plays an important role. The more impulsiveness the mother demonstrates in her behavior, the less the girl is disposed to this strategy; she tends to demonstrate behavior opposite to the maternal example. This tendency could be caused by the child's perception of emotional reactions as unpleasant, difficult to endure. Possibly the more strongly the mother expresses her emotions, especially anger, the less the child feels able to endure this strong expression. Fear of this situation may lead the girl to difficulties in reacting and seeking psychological defense mechanisms. Furthermore, gender-specific upbringing of girls places a taboo on aggression, which may motivate the child even more than the example of her mother's impulsive behavior.

At the age of 7-9, actual threats to the child increase and this is connected with the defense of personal identity. The probability of the "projection" defense mecha- 
nism appearing in the child's behavior increases with a higher level of maturity of maternal psychological defense mechanisms. Projection makes it possible to place negative traits and experience outside the boundaries of the "I" and preserves the child's positive self-image. Our research results allow us to conclude that gender influences the formation of a child's individual defense system. Development of male specifics of a defense system is typical for boys. Girls don't have close correlations with the maternal defense mechanisms. At this age, the child successfully interiorizes the maternal example of "seeking and getting support" as a desired strategy, which protects her from threats to her self-identity.

\section{Ontogenetic specifics of psychological defenses of children 10-12 years old}

Conditionally, we can define the age 10-12 as pre-pubertal. Some premises of adolescent self-identity crises may already appear at this time. Correlations between maternal and child PDM systems decrease, which could be caused by the child's increasing autonomy, consciousness, and expanding circle of significant persons. The influence of the maturity of maternal psychological defense mechanisms on specifics of the child's defense system declines. A deficit of maternal defensive resources is compensated by the child's own psychological resources.

Correlation between the psychological defense mechanisms of mother and child at the age of 10-12 can be characterized by interiorization of the defenses acquired from conscious maternal teaching. We found correlations between intentional maternal teaching of displacement, compensation, and reconciliation strategies, and the appearance of these strategies in the child's behavior.

Displacement, which means transferring one's reaction to an object that is not able to resist, can appear as a conscious mechanism of expressing negative emotions. In the process of teaching a child displacement, the mother can safely choose an appropriate object for the expression of feelings. At the age of 10-12, the child has the necessary abilities for consciously searching for objects that are appropriate to express the emotions, and avoiding spontaneity and venting negative emotions on family members, pets, and others. Compensation and reconciliation defenses in conflict situations form a base for the child's adaptation in different situations.

The correlation between maternal and child behavior remains strong with respect to intellectualization. At this age, intellectualization becomes actualized in the context of the general development of logic thinking, self-consciousness, and reflection. In general, there is a correlation between the intensity of the maternal and child defense systems. Considerable maternal psychological defenses may be connected with a low level of consciousness and maturity of psychological defense mechanisms; this situation can reveal neurotic symptoms and create intensity in relations between mother and child.

We suggest that the gender factor at this age period substantially influences the correlation between maternal and child psychological defense mechanisms. Boys' defense systems become more autonomous, and maternal influence decreases. Many mothers during the structured interview noted that their sons, at the age of 10-12, claim to be more independent and stronger than earlier, don't feel the need for advice and help, or to share their difficulties with their mother, and have changed a good deal in general. This can be a symptom of increasing autonomy 
of the son's psychological defense mechanisms from the mother's. Girls' and their mother's defensive systems correlate. Girls are disposed to interiorize displacement and defensive aggression in the process of maternal teaching

According to our research results, at the age of 10-12, the need for additional support becomes especially great. The child does not feel enough protection from external and internal threats. Acquiring new effective defensive and coping mechanisms is important for her/his ability to manage the situation. This process may be related to the child's maturation and changes in the dominant level of the life-support system. The need for additional support also shows the untenability of some defense strategies and triggers the development of new coping strategies in the next age period.

In this age group, we did not find a correlation between the maturity of maternal psychological defense mechanisms and the specifics of the child's psychological defense mechanisms. Individual factors of personal experience and social environment start to have more influence and the maturity of the mother's psychological defense mechanisms remains secondary.

Therefore, at the age of 10-12, the level of isomorphism of maternal and child psychological defense mechanisms decreases, and gender specifics begin to play a leading role in further formation of defense styles. Discussing and teaching defense strategies become important for the development of psychological defense mechanisms. At this age, the mother needs to be actively involved in the theoretical and practical teaching of defenses, because the child is getting ready to acquire knowledge about defensive behavior through dialogue. The psychological resources of the 10-12-year-old child allow him or her to proceed to the next level of a lifesupport system: coping.

\section{Conclusion}

Our research validates and helps to explain previous research findings about children's psychological defenses. In particular, we validated thesis of J. Bowlby (1982) about the child's attachment to the parents and tendency to take after the parents (as in the imprinting process), relative to the psychological defense system. Our empirical data allow us to suggest that child and maternal psychological defense mechanisms have an isomorphic development. We noted specifics of this isomorphism in different age periods.

Cramer and College (2000) found that the prevailing psychological defenses in school age children are denial and displacement. We have clarified and broadened ideas about possible individual differences in children's prevalent psychological defenses connected with the maternal factor. We found correlations between the maturity of maternal psychological defense mechanisms and specifics of the developing child's psychological defense mechanisms. We conclude that the maturity of the mother's psychological defense mechanisms provides congruence in teaching her child defensive behavior, and defines the prevalent type of reaction to frustration and the instruments of interpersonal defenses. It has maximum significance for children 4-6 years of age, for providing effective adaptation to actual threats to self-identity.

General patterns in the development of a child's defense system which appeared in our research: 
1. The child feels maximal stress intensity at age 7-9. This fact may point to the special significance of this age for forming the child's defense system.

2. The child's need for additional support increases at age 10-12, which indicates the necessity of overcoming defensive behavior and rising to conscious levels of self-regulation.

Also we validate and broaden the understanding of the statement of L.S. Benjamin (1974) about defensive and additive reactions of the child to the mother's behavior. We proposed that imitation of and adjustment to the mother's behavior are also typical for developing the child's psychological defense system, and that the individual choice of a child's reaction depends on that child's age and gender.

Each age period gives an individual picture of the child's psychological defense mechanisms and the extent of isomorphism of the defense systems of mother and child. At earlier stages of ontogenesis, the mother's defensive behavior has a dominant role. At 10-12 years, the child becomes maximally sensitive to consciously learning defense strategies, because of the specifics of intellectual development, increasing self-consciousness, and reflection.

Both age and gender play important roles for the ontogenesis of the child's psychological defenses. Gender correlates with the extent of isomorphism of child and maternal psychological defense mechanisms, the child's sensitivity to certain defenses in maternal behavior, and the child's success in learning defense strategies. At age 10-12, a girl's psychological defense mechanisms tend to preserve relationships with those of her mother, whereas a boy's psychological defense mechanisms become relatively autonomous.

Further scientific investigation is needed about the influence of both parents on developing the child's system of psychological defenses and coping strategies; about maternal attitudes toward the child, which help to form the child's resistance to stress; about the specifics of stressful situations and coping strategies in oneparent and two-parent families; about creating and refining methods to diagnose the maturity of the maternal psychological defense system and instruments for its development. Also the definition of maturity of the psychological defense system needs further clarification.

\section{Limitations}

This study does not investigate the father's influence on his child's psychological defenses. Only mothers participated in research; we based this decision on the premise that they are the closest adults for a child. The earliest ontogenetic periods are not included in the study, because of difficulties in diagnosing a child's psychological defenses at this age. Taking into account these limitations, we can extend our conclusions about correlations between maternal and child psychological defense mechanisms to the general population of children only in three age groups: 4-6 years old, 7-9 years old, and 10-12 years old, and only if the mother is the closest adult to a child. We investigated correlations, but not cause-effect relations, between maternal and child psychological defense mechanisms, and we focused only on certain parts of the process of developing a child's psychological defense mechanisms in ontogenesis. 


\section{References}

Ainsworth, M. (1977). Infancy in Uganda. Baltimore: Johns Hopkins University Press.

Asmolov, A. (2007). Psychology of personality: cultural-historical understanding of human development $3 d$ edition [Psikhologia lichnosti: kulturno-istoricheskoe ponimanie razvitiia cheloveka]. Moscow: Academia.

Belova, A. (2011). Zakonomernosti vozrastnoi dinamiki psikihologicheskih zashchit v detskom vozraste [Mechanisms of age dynamics of psychological defenses in infancy]. Vestnik Yaroslavskogo gosudarstvennogo universiteta [Yaroslavsky State University Bulletin], 4(18), 98101.

Benjamin L.S. (1974). Structural analysis of social behavior. Psychology Review, 81, 392-425. doi: $10.1037 / \mathrm{h} 0037024$

Bowlby, J. (1982) Attachment and loss. New York: Basic Books.

Cramer, P. \& College, W. (2000). Defense mechanisms in psychology today: Further processes for adaptation. American Psychologist, 55(6), 637-646. doi: 10.1037/0003-066X.55.6.637

Docenko, E. (2009). Psikhologia lichnosti [Psychology of personality]. Tyumen, Russia: Izdatelstvo Tyumenskogo gosudarstvennogo universiteta.

Eidemiller, E. G., \& Yustickis, V. V. (1999) Psikhologia i psikhoterapia semyi [Family psychology and psychotherapy]. St Petersburg: Piter.

Elkonin, D. B. (1999). Psikhologia igry [Psychology of play]. Moscow: Vlados.

Filippovich, V.I. (2014). Vzaimosviaz zhiznestoikosti i psikhologicheskih zashchit pri pogranichnyh psikhicheskih rasstroistvakh i v norme [Interconnection of hardness and psychological defenses in the normal state and in borderline mental illnesses]. Vestnik KemGU [Bulletin of Kemerovo State University], 4(60). Retrieved from: http://cyberleninka.ru/article/n/ vzaimosvyaz-zhiznestoykosti-i-psihologicheskih-zaschit-pri-pogranichnyh-psihicheskihrasstroystvah-i-v-norme.

Freud, A. (1936). Ego and the mechanisms of defense (Vol. 2). In The writings of Anna Freud: 8 Volumes. New York: Indiana University of Pennsylvania.

Kostikova, I.V. (2000). Vvedenie v gendernye issledovaniia: uchebnoe posobie [Introduction to gender research: Tutorial]. Moscow: Moscow State University Press.

Kuftyak, E.V. (2012). Faktory stanovleniia sovladaiushhego povedeniia v detskom i podrostkovom vozraste [Factors of developing coping behavior in infancy and adolescence]. Psikhologicheskie issledovaniia [Psychological Studies], 2(22), 4-6. Retrieved from: http://psystudy. ru.

Kuftyak, E.V. (2013). Razvitie psikhologii semeinogo sovladaniia [Development of the psychology of family coping]. Vestnik Kostromskogo gosudarstvennogo universiteta im. N. A. Nekrasova. Seriya "Pedagogika. Psikhologiia. Sotsialnaia rabota. Yuvenologiia. Sotsiokinetika" [Kosotroma State University Bulletin. Series "Pedagogy. Psychology. Social work. Juvenile Studies], 3(19), 139-144.

Leontiev, D.A. (2009). Labirint identichnostei: ne chelovek dlya identichnosti, a identichnost dlya cheloveka [Labyrinth of identities: Not a person for an identity, but an identity for a person]. Filosofskie nauki [Studies in Philosophy], 10, 10-11.

Nikolskaia, I. M., \& Granovskaya, R. M. (2001). Psikhologicheskaia zashchita u detei [Child psychological defense]. St Petersburg: Rech.

Nikolskaia, I. M. (2010). Metod seriinyh risunkov i rasskazov - novaia art-terapevticheskaia tekhnologiia [Method of serial drawings and stories - a new art-therapy technology]. Voprosy psikhicheskogo zdorovia detei i podrostkov [Issues in Children's and Adolescents' Mental Health], 2, 13-28. 
Nikolskaia, I.M. (2012). Rol psikhologicheskoi zashchity v okazanii krizisnoi psikhologicheskoi pomoshchi detyam [The role of psychological defense in providing psychological support for children in crisis]. Meditsinskaia psikhologiya $v$ Rossii: elektronnii nauchnyj zhurnal [Medical Psychology in Russia: Scientific E-journal], 5 (16). Retrieved from: http://medpsy.ru

Plutchik, R., Kellerman, H., \& Conte H. R. (1979) A structural theory of ego defenses and emotions. In C. Izard (Ed.), Emotions in personality and psychopathology (pp. 229-257). New York, NY: Plenum Press. doi: 10.1007/978-1-4613-2892-6_9

Portnova, A. G., \& Bogomolov, A. M. (2008). Psikhologicheskaia zashchita v kontekste sotsialnopsikhologicheskoi adaptatsii i razvitiia lichnosti: monografiia [Psychological defense in the context of socio-psychological adaptation and development of personality: Monograph]. Tomsk: Izdatelstvo Tomskogo gosudarstvennogo pedagogicheskogo universiteta.

Romanova, E.S., \& Grebennikov, L. R. (1996). Mekhanizmy psikhologicheskoi zashchity: genezis, funktsionirovanie, diagnostika [Mechanisms of psychological defense: Genesis, functioning, diagnostics]. Mytishchi: Talant.

Sokolova, E.T. (2011). Phenomenon of psychological defense. Psychology in Russia: State of the Art, 4, 204-225. doi: 10.11621/pir.2011.0012

Sokolova, E.T. (1989). Samosoznanie i samootsenka pri anomaliiakh lichnosti [Self-consciousness and self-esteem under conditions of personality anomalies]. Moscow: Moscow State University Press.

Solovyova, A. V. (2013). Psikhologicheskaia zashchita v podrostkovom vozraste: sushchnost, soderzhanie, prichiny [Psychological defense in adolescence: Concept, content, reasons]. Moscow: Flinta.

Ushakova, M. Yu. (2006). Gendernye osobennosti rechi detei doshkolnogo vozrasta [Gender specifics of children's speech in pre-school age]. (Unpublished candidate dissertation). Irkutsk State Pedagogical University, Irkutsk, Russia.

Vasserman, L.I., Eryshev, O.F., \& Klubova, E.B. (2005). Psikhologicheskaya diagnostika indeksa zhiznennogo stilya [Psychological diagnostics of the Life Style Index]. St Petersburg: Izdatelstvo SPBNIPI im. V.M. Bekhtereva.

Vygotsky, L. S. (1982) Problemy obshchej psikhologii. In Sobranie sochinenii v 6 tomakh [Collected works in 6 volumes]. Vol. 2. Moscow: Pedagogika.

Winnikott, D. V. (2002). Igra i realnost [Playing and reality]. Moscow: Institut obshchegumanitarnikh issledovanii.

Original manuscript received January 27, 2016

Revised manuscript accepted July 07, 2016

First published online September 30, 2016 